by then so fully engaged in research and teaching that he was unwilling to retrace his steps in order to comply with the regulations necessary for taking a degree. This rather unorthodox entry to the academic world in some degree recalls that of Gowland Hopkins, who was first an articled pupil to a public analyst: he moved to Guy's Hospital Modical School, where he took a medical degree, but only in time snatched from research and teaching commitments. It may be that academie life will be the poorer now that insistence on 'paper qualifications' has made such unusual débuts all but impossible. During these early years, Marston received much help from Archibald Watson, the professor of anatomy, of whom he always spoke with affection, as well as from Brailsford Robertson.

His first paper adumbrated the importance of the mitochondria as centres of enzyme activities - a concept since amply confirmed. In other papers he showed for the first time that the mammary gland of the monotreme echidna did indeed secrete true milk, described the first micromethod for the determination of guanidine and methyl guanidine, and published work on the sterol isolated from the 'giant toad stool'.

In 1927 he joined the Division of Animal Nutrition of the (then) C.S.I.R., newly formed under Brailsford Robertson. He was in charge of the Division between Robertson's death in 1929, and the appointment of Sir Charles Martin as chief in 1930. A close bond grew up with Martin, and when he returned to England in 1932, Marston was appointed chief nutrition officer, and placed in charge of the Nutrition Laboratory, which became part of the Division of Animal Health until 1944, when the Division of Biochemistry and General Nutrition was established with Marston as its first chief. During this period the researches of Marston and his colleagues covered a wide field and had important practical applications. While he always insisted that advances in practice depended on an understanding of the underlying natural phenomena, he nevertheless tried to ensure that the practical means of applying scientific principles were available. Among other subjects, the work included valuable fundamental researches on the animal's requirements for protein for the manufacture of skin and wool and on the special need for sulphur-containing amino-acids (now, but not then, common knowledge). He early observed the effect of copper on keratinization and hence on the quality of wool. Other work dealt with the requirements of the sheep for phosphorus, and of the effects on it of thyroidectomy.

In 1936 he was invited by Hopkins to spend a year in the Biochemical Laboratory, University of Cambridge. There he continued his work on carbohydrate fermentation by ruminal micro-organisms, and interested Joseph Barcroft in general problems of ruminal function, with most fruitful results.

During the Second World War he furnished, with his colleagues, valuable information to the Army on available human rations, and compiled highly useful dietary tables. After the War he worked on the basic problems of energy transactions in ruminants. The work for which he is most widely known can be traced to its beginnings in 1933, when he became interested in 'Coast disease'. Considerable stretches of land, among them the 'ninety mile desert' near his birthplace, would support neither useful erops nor domestic stock. This was (wrongly) ascribed to phosphorus deficiency. Marston and his colleagues showed that phosphorus was adequate, but that there was a lack of cobalt and copper, and in certain areas of zinc, and that traces of such elements would permit the normal growth of both plants and animals. These fundamental discoveries proved the key to the solution of difficulties encountered by agriculturists and pastoralists in other continents besides Australia, and gave impetus to the conception of the importance of heavy metals in biological processes which is still growing. Marston was able to show that cobalt was effective only after it had been incorporated into vitamin $B_{12}$ by ruminal micro-organisms, and that at least one of its functions in the body was that of co-enzyme in certain isomeric changes. The story must now be left to other hands to unfold: that there are further chapters is certain.

Marston was widely read, and widely travelled, both in Europe and the United States, with a fund of reminiscences of people and places. In 1957 he was elected D.Se. honoris causa (his first degree) by the Australian National University, and in $\mathbf{1 9 5 9}$ to a D.Sc. of the University of Adelaide ad eundem gradum. He was invited to lecture on the work of the Division to the Royal Society of London in 1948, and was elected Fellow in 1949. In 1951, Sir Mark Oliphant and he were active in the foundation of the Australian Academy of Sciences, of which they were original members. He numbered among his close friends not only scientific colleagues such as Martin, Hopkins, Rivett, Oliphant and E. V. MeCollum, but also famous artists, and leaders in the industrial world such as W. S. Robinson in Australia and J. L. Pratt and Robert Kleberg, jun., in the United States. Perhaps from such contacts sprang some of his sympathy with practical problems.

E. G. Holmes

\section{Prof. Arthur Holmes, F.R.S.}

Arthur Holmes, emeritus professor of geology and mineralogy in the University of Edinburgh, died on September 20 at the age of seventy-five at his home in Putney. His brilliant research on the wider problems of geology has earned him his place as one of the great Earth scientists of the century.

Holmes was born at Hebburn, near Newcastle-uponTyne, in 1890. He graduated at the Imperial College of Science and Technology in 1910 and undertook an expedition to Mozambique in 1911. Here an attack of blackwater fever nearly ended his career (there was in fact an announcement of his death in the local paper), but he came back to rejoin the staff of Imperial College until 1921. He then joined the Yomah Oil Co. in Burma as chief geologist; but, fortunately for the future of geological science, he returned in 1924 to become head of the newly created Department of Geology in the University of Durham, which under his leadership rapidly gained an international reputation for petrological rosearch. In 1943 he was appointed regius professor of geology in the University of Edinburgh, which was honoured with his occupation of the chair for thirteen years, and with his presence as emeritus professor for six years after he retired in 1956 .

Prof. Holmes has exercised a profound influence on almost all branches of geology, not only through his own remarkable researches but also by his beautifully written text-books and the stimulation of the research qualities of his students. His output of publications has been prodigious-nearly 200 , including several famous text-books such as The Age of the Earth, Nomenclature of Petrology, Petrographic Methods and Calculations and Principles of Physical Geology. He has made a great number of contributions to our knowledge of the geology of many parts of the world, from his home district in the north of England to Africa, India and elsewhere; but the descriptive aspect of his work has been, far more than with most men, merely a prelude to his remarkable work on the wider genetic problems of the seience. He went deeply into the major questions of the origin of igneous rocks, partly in association with his accomplished and eminent wife, Dr. Doris Reynolds. He was never a man to shun controversy, and his work on the origin of the alkaline rocks of Africa and elsewhere, on the thorny problems of granites and their associates, on the origin and development of magmas, and on the role of metasomatism in rock genesis, has broadened the vision of igneous and metamorphic petrologists all over the world.

During his school-days, Holmes's inquiring mind had questioned the magic date for the Creation, 4004 B.C., in Archbishop Ussher's chronology for the book of Genesis, 
and in the sixth form his interest in goology was awakened by an enlightoned schoolmaster who eneouragod him to read Kelvin and suess. He was thirteen years of age when Rutherford realized that radioactivity might provide a moans for determining the actual ages of minerals, and he was an undergraduate at Imperial College when this idea bore fruit, and Boltwood (using lead ratios) and then Strutt (using helium content) approximately dated a number of uranium-bearing minerals. Working in Strutt's laboratory, Holmes became one of the pioneers in this field, and since that time he has been one of the loaders in applying the results of radioactive methods to the dating of rocks. He took a major part in the construction of a geological timo-scale in terms of millions of years - considering both post- and pre-Cambrian rocks and the age of the Earth itself.

Holmes's major work was not confined to igneous and motamorphic petrology and geological time. His contributions to the geophysical aspects of geology are classic: the nature of orogonic and opeirogenic activity, convection curronts in tho Earth's mantle, continental drift, radioactivity in geology-one could go on for a long time listing the aspects of geology to which he has made major contributions. In fact there is scarcely a main branch of the subject, other than palaeontology, with which his name is not associated. Much of his thinking was on the grand scale, applied to the broad philosophical aspects of the Earth sciences.

Holmes's distinguished career received international acclaim. $\mathrm{H}_{\ominus}$ was elected Corresponding, Foreign or Honorary Member of the Geological Societies of America, Belgium, and Stockholm, and the Academies of Science of the United States, Sweden, the Netherlands, and France. $\mathrm{H}_{\theta}$ was awarded the Murchison and Wollaston Medals of the Geological Society of London, the Penrose Medal of the Geological Society of America, the Fourmarier Modal of the Royal Academy of Belgium, and the MakdougallBrisbane Prize of the Royal Society of Edinburgh. In 1964 he shared with Prof. P. Eskola of Helsinki the Vetlesen, Prize of Columbia University, New York, for outstanding achievement in scionce relating to "a clearer understanding of the Earth, its history or its relation to the universe". $\mathrm{He}$ was a Fellow of the Imperial College of Science and Technology and an Honorary Doctor of Laws of the University of Edinburgh.

In spite of many years of poor health, Holmes continued his creative work until the end. The second edition (largely re-written and greatly enlarged) of his Principles of Physical Geology, published this year, is a masterpiece of lueid writing and shows a breadth of knowledge and vision which few men possess.

Those fortunate enough to have known Prof. Holmes found him a quiot man of oxtraordinary charm and unfailing kindness, and will remember with affoction and gratitude the help and advice which he gave so readily. In 1914 ho marriod Margaret Howe, and they had one son. His wife died in 1938, and he later married Dr. Doris Reynolds, herself a distinguished geologist.

F. H. STEWART

\section{Sir Ernest Thomas Fisk}

WITH the doath of Sir Ernest Thomas Fisk at his horne in Sydney on July 8, at the age of seventy-eight, the world lost a man who made a conspicuous contribution to the development of wireless communication.

Born at Sunbury-on-Thames, England, on August 8, 1886, he entered the Marconi Company's training school in 1906 and came to Australia in 1911 as resident engineer of a branch which the Company had opened in Sydney. $\mathrm{He}$ submitted to the Australian Government proposals for the setting up of a number of wireless stations, but his proposals were not accepted.

In the same year, the Australasian Wireless Company was formed with Australian capital to acquire and operate the patent rights of the Telefunken system. Two years later, Amalgamated Wiroloss (Australasia), Ltd., was inaugurated, and the rights of the Marconi and Telefunken. systems were acquired. Fisk became technical and general manager, and in 1917, managing director.

In Fngland in 1916 Fisk arranged with Marconi to conduct a series of tests, and in the following year he erected an experimental receiving station at Pymble near Sydney. Tests were conducted there with the viow of determining the best type of circuit to use for long-wave, long-distance reception.

Later, Fisk transferred the station to Wahroonga, another Sydney suburb, and began experiments with the Caernarvon station in Wales early in 1918. When the tests were satisfactory, arrangements were made for a public demonstration of direct wireless communication between England and Australia.

Messages to Australian newspapers wero sont from Caernarvon by the then Australian Prime Minister, Mr. W. M. Hughes, and the then Australian Minister for the Navy, Sir Joseph Cook, who were in England at that time. Thoso, the first direct wireless messages between the two countries, were received at Fisk's Wahroonga station and delivered to tho Sydnoy Press.

Later, the experimental receiving station was transferred to Koo-wee-rup, in Victoria, where the scope of the work was extended, new apparatus was installed, and continuous day and night observations made of signals from all high-powered stations in Europe and the United States.

The Koo-wee-rup experimonts established that wiroless waves from England to Australia followed the course of the greatest darkness - a discovery which ultimately was of immense value when aerials for the short-wave sorvice were being designed.

As an outcome of successful experiments, Fisk, on behalf of Amalgamated Wireless in conjunction with the Marconi Company, in 1921 offered to establish a direct wireless servico between Australia, and Groat Britain and to transmit messages at rates one-third less than existing cable charges. The proposal, which was strongly opposed by exponents of a rolay system, found champions in $\mathrm{Mr}$. W. M. Hughes and Genoral Smuts of South Africa. Thoy opposed the relay system and made it clear at the Imperial Conference in 1921 that their respective countries would proceed with direct communication.

Strengthened by the positive attitude of Mr. Hughes, Fisk persisted with his advocacy of a direct service, and in March 1922, on behalf of Amalgamated Wireless, signed an agreement with the Australian Government. under which the Company was to establish and maintain direct wireless communication between Australia and the United Kingdom and Canada, and to assume control of existing coastal and island wireloss stations. The Government acquired 50 per cent of the shares in the Company plus one to give it a bare majority, the remainder of the shares being held by privato shareholders.

Fisk was not daunted by the refusal of the British Government to grant a licence to the Marconi Company to erect a high-power station in England. The experiments were continuod, and in January 1924 tho first transmission. of short-wave signals was received from the Marconi station at Poldhu, Cornwall. In August of that year, a fresh agreomont was entered into with Amalgamated Wireless to erect short-wave transmitters with directional aerials to provide service to Great Britain and to Canada when corresponding stations woro built in those countries. Fisk's foresight and initiative were rewarded in 1927 with the opening of the Boam Service to the United Kingdom, and in 1928 to Canada.

Commenting that the Company had fought against powerful opposition, Royal Commissioners who investigated broadcasting within Australia reported to Federal Parliament in 1927 that the Company, Fisk and his officers were "entitled to great eredit for tho establish- 